\title{
(Not) being at home: Hsu Ming Teo's Behind the Moon (2005) and Michelle de Kretser's Questions of Travel (2012)
}

\author{
*Janet Wilson \\ Department of English, University of Northampton, Northampton, UK
}

*Email: Janet.Wilson@northampton.ac.uk

This article examines some interventions of Asian Australian writing into the debate over multiculturalism, and the shift from negative stereotyping of Asian migrants, to reification of racial divisions and propagation of a masked racism, to the creation of new alignments and the revival of pre-existing affiliations by migrant and second generation subjects. It compares the practices of not-at-homeness by Asian migrants and their descendants and white Australians in Hsu Ming Teo's Behind the Moon with those of a Sri Lankan refugee and a white Australian traveller in Michelle de Kretser's Questions of Travel. The changing concepts of belonging in the novels show a realignment of core and periphery relations within the nation state under the pressures of multiculturalism and globalization: where home is and how it is configured are questions as important for white Australians whose sense of territory is challenged as they are for Asian migrants who seek to establish a new belonging.

Keywords: Hsu Ming Teo; Michelle de Kretser; multiculturalism; white Australian; not-athomeness; Asian Australian writing; diaspora subjects

\section{Asian Australian writing and (not)being at home}

The problematic positioning of people of Asian descent in Australian society has been well noted by Ien Ang (2001): due to "masked racism" there is an "ambivalent and apparently contradictory process of acceptance through difference, inclusion by virtue of othering" (139; emphasis in original; quoted in Madsen 2006, 118). The migrant subject inhabits a liminal "third space" being "neither here nor there" (Madsen 2006, 120), experiencing "ambivalent hospitality" that enables a diasporic lifestyle but not complete belonging. Such dislocated migrant subjectivities as seen through forms of 
othering - such as exoticization, misrecognitions and misappellations, as well as more blatant racial discrimination -- point to tensions and contradictions within Australian multiculturalism, and the fundamental ambivalence that comes from white people no longer being positioned at the centre of the national space (Hage 1988, 19). These critiques reflect the familiar argument since the inception of official multiculturalism in the 1970s, that it is little more than a progressive tweaking of the assimilationist imperative (Dickens 2015): that is, in order to manage cultural difference multiculturalism claims to foster ethnic diversity and equality and to redefine the centre and periphery binary, but nevertheless it creates increasingly subtle forms of discrimination and exclusion suggestive of a masked racism.

The rapidly expanding field of Asian Australian writing constitutes an intervention into the debate over cultural and racial divisions and exclusions, one that challenges the limits of hegemonic multiculturalism. The dissident potential of multicultural writing has often been noted and can be traced to the origins of the core culture, the Anglo Celts, which provides an "oppositional model" of difference (Gunew 1990, 115-116). ${ }^{1}$ In many Asian Australian fictions, however, the AngloCeltic core is represented as homogeneous; identities of Asian Australian and Indigenous Australian minorities are introduced to "dismantle racially discriminatory structures and institutionalized inequality" (Khoo 2008, 4) and to unmask Anglo Celtic cultural dominance. As Ghassan Hage points out this often includes nonAnglos who define themselves as white Australians (19, 20). Pioneering novels such as Brian Castro's Birds of Passage ([1983] 1989), Yasmine Gooneratne's A Change of Skies (1991), and Michelle de Krester's The Lost Dog (2007) expose subtle forms of "othering", such as being exoticized or domesticated in the white Australian neoliberal consciousness. Yet mixed race and migrant subjectivities also show 
themselves as able to acquire new agency in their intersections with traditional multicultural sensibilities by harnessing or resisting the global and transnational forces which inflect their actions (Dickens 2015, 88). ${ }^{2}$ Forms of contemporary mobilization, therefore, increasingly frame the way that Asian Australian writing renegotiates and redefines ethnic stereotypes and challenges discriminatory mechanisms by contesting, queering and repositioning Anglo Australian norms. Recent novels about the migrant experience, and especially the second generation, contemplate a new national imaginary, animated by global forces, consisting of multiple kinds of belonging and more inclusive versions of Australianness: Miss Yipsoon, the Chinese teacher in Behind the Moon, stakes this claim: "We're all Australians now" (Teo 2005, 60).

This article compares two Asian Australian novels, Behind the Moon (2005) by Hsu Ming Teo and Questions of Travel (2012) by Michelle de Kretser, and their reconfiguring of new types and degrees of (not) belonging emanating from both the migrant outsider and the Anglo Celtic subject within the hybridized, creolized spaces of the Australian hostland. In referring to their constructions of gendered and racial difference and ethnic hybridity, it follows on from Wenche Ommundsen's (2012) discussion about the transnationalism of current Asian Australian writing, to suggest that the multicultural national imaginary has developed from the "ambivalent $[\ldots]$ acceptance" that Ien Ang noted in 2001, to show alternative structures of selfdetermination to forms of "othering" within the core-periphery binary. These signs of multicultural diversity and agency on the one hand, and changes within the white Australian consciousness on the other, can be approached from within the framework of home and belonging. 
Underlying the narratives of both texts is the question of how to belong: the uprooted, unsettled migrant who confronts his or her own lack of Australianness triggers reassessment by Anglo Celtic Australians of their sense of place and entitlement as endowed by whiteness. In both, the cross-cultural encounter reverberates with the tensions that occur when ethnicity is no longer defined by home, and home is no longer synonymous with place. In their questioning of geographical constructions of home, the novels illustrate how this absence leads to compensatory imaginings: an idealization of the archaic homeland or "unlearning" practices and reconstructions of "(not)being-at-home" from alternative positions and sites.

Hsu-Ming Teo's Behind the Moon is a multicultural narrative of Australian city life in the suburbs historically framed by Asian migration following the Vietnam War intersected by a transnational Australia - US journey in the novel's con temporary moment. A bildungsroman about three young people, it traces their multiple, changing understandings of home and belonging; in the conclusion, Sydney, where they meet and grow up, becomes the site of their alternative community. By contrast, De Kretser's Questions of Travel is a $21^{\text {st }}$-century global novel with contemporary settings in the UK, war-torn Sri Lanka and Sydney, where most of the definitive action takes place. Unexpectedly, it endorses the archaic return to the ancestral homeland of Sri Lanka, a decision which seems to undermine the cultural and personal impact of the new media and technologies in the novel. These are associated with the globalization of culture, tourism, and homeland return visits that supposedly enhance life in the diaspora by facilitating interconnectivity, increasing affiliations and enabling new forms of belonging. Tracing the intersecting trajectories of a white Australian traveller to the northern hemisphere and a Sri Lankan refugee to 
Australia, De Kretser raises a range of questions about the growing absence of home in their lives.

Being at home and how to be at home, issues which preoccupy the protagonists of both novels (whether seeking belonging, living with being alienated, or identifying with the ancestral homeland), are states that are constantly infiltrated by their opposite, of not being at home, or the Freudian concept of the unheimlich, a view of human subjectivity which Freud ([1919] 1959) in "The Uncanny" links to our unconscious or repressed desires. Associated with non-acceptance by or alienation from the host society, the unheimlich/estrangement in the novels reflects those problems of translation occurring at the "boundaries of cultures where meanings and values are (mis)read or signs are misappropriated" (Bhabha 2006, 155); in these cases, due to the failure of the hostland to live up to the meaning of the original homeland, and provide an equivalent sense of home. This distinction forms the basis of Jane Mummery's (2006) argument that hyphenated, hybridized individuals and communities, unlike others, are constituted in terms of practices and actions of not-athomeness; that is "they are not at home in any attempted definitions of them by the 'they', regardless of whether the 'they' is the host, the homeland or the wider diasporic community" (38). Such alienation means that diaspora subjects also cling to more complex, idealized values of at-homeness such as continued identification with the ancestral or originary homeland and emotional attachment to the mother tongue. More suggestively, Mummery argues that the hyphenated and divided states of being characteristic of migrants and their descendants should not be configured as an alternative identity in diaspora to that of the nation state (and so run the risk of being closed off), but in the form of a more porous practice of not being at home in terms of potentiality and becoming (41-42). Such practices can be linked to Bhabha's (1994) 
idea of the performative space in the nation culture for minority cultures, who embrace the status of becoming (157); and to Deleuze and Guattari's (1992) nonevolutionary idea of becoming as a reality that is involuntary, non-filiative and nonhereditary, and which concerns alliances or "transversal communications between heterogeneous populations" (239).

Both novels show practices of not-at-homeness and the unlearning of familiar cultural constructions undertaken not just by alienated migrant characters but also by disconcerted, decentred white Australians in response to the multicultural pressures of ethnic minorities. As Mummery points out, referring to a range of western philosophers, the hyphenated or divided identity that reflects not-at-homeness is in fact a feature of the human condition $(2006,42)$. But the disruptions caused by migration in which the subject's idea of a temporal continuum differs from both the new host society's official discourses about time and those of their original home, demands some reconfiguration of identity structures. Living diasporically, as Chinese Canadian author Larissa Lai (2001) writes, is "to be without a resting place, without a home-place, constantly in motion and constantly in question" (9). For white Australians as well, perceptions of not-at-homeness, often involve a challenge to supremacist ideas of whiteness based on their position of race privilege and cultural practices assumed to be the norm within the nation state: they involve semi-repressed, even violent, irrational behaviours, as well as a conscious recognition of difference. The quest for greater belonging by both Asian Australian and white Australian subjects, enacted through practices of not-belonging, leads to reconstructions of idealized states of home and belonging constituted as fixed points. In both novels they move towards new positions and alternative alignments in response to the flux of the concept of at-homeness, whether building a diaspora community (Teo), joining a 
globally-based one, or returning to the nation-state (De Kretser). These practices and positions suggest realignments in core and periphery relations, and their fictional representations demonstrate a significant difference in each writer's attitude towards multiculturalism.

\section{Hsu-Ming Teo, Behind the Moon (2005)}

Behind the Moon can initially be read as an assault on multiculturalism, exposing its limits as the product of a white Anglo Celtic culture which recognizes official national categories such as family, gender, language, and ethnicity but which ignores more subtle differentiations of identity and subjectivity. Teo queers these foundational categories of Australian nationhood and their underpinning assumptions with the ironic self-awareness that is by now familiar in migrant voices. She focuses on a trio of young friends, the "multicultural reject group" (Teo 2005, 61) that does not fit in. As characters in transition, their search for identity and fulfilment through family, marriage, love, sexual gratification or other forms of intimacy is marred by mistaken identities, misalliances, and disharmony, and further complicated by racial discrimination and abuse. Yet the three protagonists ultimately realize that reconciliation of their differences and recognition of their bonds of affection works more effectively than their individual struggles in a society whose gendered, ethnic norms they disturb and which offers only the ambivalent and limited acceptance that Ang identifies $(2001,39)$. Their multicultural alliance determines a new way of being at home, one which indirectly answers the novel's enquiry into the raced, gendered, and sexualized basis of constructions of Australian nationhood.

In its critique of white Australianness and multiculturalism, Behind the Moon is comparable to Brian Castro's novel Birds of Passage, which uses intertextual 
allusions to Banjo Patterson's ballad "The Man from Snowy River" to challenge the seminal outback myth of white male mateship in a narrative of the racialized Chinese of the 1860s gold rush. As Robin Morris (2008) demonstrates, Teo ironically reinvokes mateship as a form of male bonding and a core component of the foundational myth of the nation which developed from historical accounts of the Dardanelles campaign of World War One. This is hinted at in the poster image on Justin Cheong's wall, taken from Peter Weir's blockbuster film, Gallipoli (1981). But Teo's vision of a new multicultural model of union consisting of three ethnically marginalized voices demarcates an alternative politics of location to that of the original identificatory myth: "When they are together $[\ldots]$, they are no longer living on the fraying fringes of a difficult and hostile world" (363). This asexual liaison based on emotional ties of love and affection can also be considered as a not-being-athome practice which opens up to new possibilities of belonging and becoming; as a multicultural alternative to the predominantly male "mateship" model of being at home, it consolidates the novel's critique and displacement of masculinized, heterosexual frames of belonging which in the literary tradition have been mythologized as central to Australian nationhood.

The "multicultural reject group" (Teo 2005, 61) first meet at school in Strathfield, a lower middle-class inner western suburb of Sydney where more fluid interconnections and social dynamics are possible than in the more cosmopolitan and elite eastern suburbs. Their confused encounters after they leave school, complicated by gender differences and their hybrid ethnic identities, undermine their early friendship as attempts at intimacy end in disaster and alienation. The novel dramatizes their independent pathways and moments of illumination that take them beyond the social stereotyping, gender and ethnic discrimination that, it is implied, have 
subverted the potential for finding a way to balance their aspirations with opportunity. The gay Chinese Australian Justin Cheong, described as "ordinary" and "such a stereotypical Australian-born Chinese boy that he was virtually invisible" (13), attempts to develop his body mass and improve his appearance so as to be more attractive to white men and find an "empowering white multiculturalism" (328); in this queering of normative Australianness, he eventually suffers the consequences of being both Asian and gay. Beaten up by Australian racists and anti-gays he remains in a coma at the novel's end, but realizes that ethnic, gendered labels and appellations ultimately are meaningless when he wants to identify who he "really" is.

The multiracial Tien Ho, a refugee from Vietnam, is part Vietnamese, part Chinese, and part black American. After the failure of her marriage to a young Chinese medical student-turned-artist she returns from the USA after hearing of Justin's near fatal attack, vowing to remain at his side: earlier she had imagined herself to be in love with him. The third member is the Australian, Nigel Gibson, nicknamed Gibbo, whose obesity and lack of sporting and social skills make him an outsider at school. In order to "explain" himself, Gibbo speculates that he might have some Chinese ethnicity and that joining an multi-ethnic group might overcome his outsider status: "Two could still be class rejects: three were a gang!” (Teo 2005, 54). Raised in terms of core Aussie values he goes to the opposite extreme and worries that his "not-quite-Australianness" will exclude him from the ethnic loop of "intrinsic Asianness" (61) that Justin and Tien share. He too is reunited with the others at the novel's end because his strongest attachments are to them.

Behind the Moon is comparable to other novels that can be read as multicultural bildungsromane, such as Monica Ali's Brick Lane, a study of different factions in the Bangladeshi community of East End London. Like Ali, Teo develops 
her narrative imaging of a divided and tense inner city community by using stereotypes to indicate the positions of the trio's families on the spectrum of ethnicity and belonging (see Perfect 2014, 116). In terms of diaspora theory, Teo's narrative also illustrates what Alexandra Watson calls "the diasporic slide", the heritage of second generation children who struggle with their first generation diasporic parents' lack of social ease in the hostland, and their high expectations of their offspring which make them feel caught between cultures (Watkins 2016, PAGE). The conventional middle class Chinese parents of Justin, who aspire to assimilate: his doctor father, who sings karaoke in his den at home, and his anally retentive mother Annabelle, expect their son Justin should conform. By contrast the "mongrel roots" (Teo 2005, 72) of the multi-ethnic refugee Tien prevent her from being accepted by her extended Vietnamese family with whom she initially lives, and she rebels against her mother, Linh Ho, when she finally arrives in Sydney. Teo represents intergenerational conflict more broadly, however, by emphasising white Australian family tensions, namely the disappointment and confusion that Gibbo's father Bob, a Vietnam War veteran, experiences at his son's non-conformity. She explores the limits of the multicultural ideology of inclusion across the generations, however, by focusing on submerged conditions of the second generation: Justin's gay sexuality, Tien's complex ethnic hybridity, her mysterious origins which lead to her search for her black American father in the USA, and Gibbo's impression that being a white Australian male is insufficient; his uneasy relations with his family evidences the reduction in symbolic value of the white Australian majority.

The novel challenges the exploitative and superficial elements of multiculturalism through incidents and situations that expose the ideology's flaws while also pointing to its potential for encouraging social improvement. Teo 
introduces alternative notions of Australianness that subvert "the conflation of race, face and nation" (Tan 2008, 77), and caricatures national stereotypes such as fears about an "Asian invasion", associated with the White Australian policy:

ordinary Australians teetered on the verge of victimhood, clinging on with a death-grip to a nostalgic past when unity of race had ensured equality in the nation and they cast panic-stricken glances around for someone to blame for all their gut-roiling fear. (Teo 2005, 198)

Gibbo's construction as a distorted, off-centre image of white Australian masculinity, in particular, further undercuts the "norm" that Teo's satire targets. Indeed, he represents an ironically reversed image of the dislocated, hyphenated migrant. Nevertheless he represents potentiality and becoming for, like the Asian diasporan, he practises not being at home. Aptly nick-named "Gibbo", he is "not-quite-Australian" (61) in his desire to imitate and resemble the other, that is, to embrace Asianness, so contrasting with Justin's desire to be attractive to white men.

In this characterization the novel hints at colonial structures from which the nation has struggled to emancipate itself through postcolonial revisioning, and Teo suggests parallels between the inequalities caused by contemporary migration and indigenous dispossession due to colonization. Tien's misidentification as an Aborigine at school - "Hey Abo" (Teo, 2005, 29) -- leads her to enquire about her father's ethnic identity. But Gibbo's ethnic identification with the Chinese -- "As long as Gibbo could remember, he wanted to be thinner and he wanted to be Chinese, just like Justin" (84) - by contrast, invokes the myth of the "unsettled settler", often associated with the desire for greater indigeneity and emerging as a new strand of 
national identity in New Zealand and Australia in the late 1980s. His rejection of white settler identity structures can be compared to those neoliberal Australians and Pakeha New Zealanders who identify with indigenous Aborigine or Maori in order to compensate for their own perceived lack of authenticity and belonging; the most recent version in Australia, following the publication of the "Bringing Them Home Report” (Australian Human Rights Commission, 1997), is a form of "settler envy" of Aboriginal trauma (Williams 1997; Huggan 2007, viii-ix; Delrez 2010). Gibbo's acts of not being at home, then, can be read in light of the already "unsettled" structures of white settler belonging, as concepts of home, the core of personal, cultural identity and social rootedness, can no longer be taken for granted. Teo's critique, therefore, also extends to his rejection of commonplace masculine activities, the leisure pursuits of his fellow engineering students: football, cricket, beer-swilling and military success. Furthermore, he is unable to develop a "blokey camaraderie" (Teo 2005, 97) with his father, Bob Gibson, who remains puzzled by his son's unaccountable sense of difference. But Bob in turn finds he is unable to live up to the "impossible ideals of Australian masculinity" (282) represented by his father, the true blue patriot Gordon Gibson, whose confused racist attitudes of "virulent hatred towards Asians", despite his grudging recognition of their claims to citizenship and belonging - "They've been here since the gold rushes. They're practically Australian" (279) -- articulates another stereotype of white Australian intolerance and discrimination. Through Gibbo's rebellion, and Bob's reactions, the novel argues that both genealogically and culturally the idealization of the masculinized core (with its origins in the Gallipoli mateship myth) can no longer be sustained.

Teo's critique and repositioning of white Australianness climaxes in the behaviour of Bob Gibson, when his tolerance and understanding finally snap. At the 
"Dead Diana" dinner party, an event hosted by the Cheongs, he attacks the Asian presence in front of his hosts, his wife and son, Tien, her fiancé, and mother, Linh Ho: overwhelmed at being outnumbered, he lashes out calling them Chinks. This is followed by the realization that his violence was motivated by a wish to regain control over his territory:

Bob couldn't help but feel bewildered by what had happened to this society, to the kids he once knew. And under his hurt and confusion there was a growing need to strike back and stake out his own territory, otherwise how was he ever going to feel at home again in the very place he'd lived in all his life? (283; my emphasis)

The novel stresses the intergenerational gap between parents who are rooted and children who are alienated due to the commodification of life and the binding glue of global youth culture. In overturning the stereotypes of gender and heteronormativity that the nuclear family values, the three friends demarcate differences from their parents' generation as well as differences between Asian and white Australian in order to create new space for a harmonious minority community. Tien's and Gibbo's decision to remain with Justin at the novel's end, catalyzed by shock at the violent homophobia and racism of his near fatal attack, urges articulation of alternative affiliations and loyalties. As a circle that stands for a "system of articulated equivalences" (Mummery 2006, 36), they circumvent the norms of marriage and heterosexuality which are too divisive and essentialist: "When they are together $[\ldots]$ they are at the stable centre of the universe and life is simply the way it should be" (Teo 2005, 363).

The formation of an alternative community based on emotions and intimacy is based on what Vijay Mishra (2007) sees as "accepting the persistence of difference 
located in the in-between within a semantics of the hyphen" (130); that is, in a complex multicultural space where the rationale of belonging resists co-option to white Australian norms and expectations, identity should not be closed off but indefinitely deferred. In terms of the politics of location, identity is derived from a simultaneity of diasporization and rootedness (Brah 1996, 242), a balance comparable to Bhabha's third space which can also be redolent of new belonging. The alternative community also suggests a practice of difference and differentiation that might be fitting for a new and revised social imaginary for, as Dipesh Chakrabarty (2011) claims, newness enters the world through acts of displacement (165-166). The renegotiated concept of togetherness and belonging which elides divisions of class, ethnicity and gender risks being oppositional and closed off in order to protect its distinctiveness. Yet the novel's closing perception is that "that place where there will be no trouble" (Teo 2005, 363) is unattainable, hinting that the new community's condition of subjecthood will consist of an engagement with what Stuart Hall (1990) calls "the continuous play of history, culture and power" (394). Teo suggests by this idealization of multiculturalism the existence of Mishra's idea of "a space for a degree of free play without necessarily endorsing any ideology" $(2007,182)$; on the periphery of mainstream identitarian politics, the minority group will nevertheless continue to interact with and impact on the white Australian majority.

\section{Michelle de Kretser, Questions of Travel}

Questions of Travel demonstrates even more insidiously than Behind the Moon the internal fragmentation of the white Anglo Celtic core. The white Australian's dislocations due to international travel and global tourism are counterpointed to the urgent journey of the Sri Lankan subject in exile, in De Kretser's contrasting portraits 
of homeland filiation. In Behind the Moon, "home" as discovered through new attachments and affiliations in the hostland, illustrates that the diasporic subject's "homing desire" is realized in relations of intimacy between self and other - an experience that "can be attached to bodies that have touched us in a meaningful way" (Fortier 2003, 131). But in Questions of Travel the absence of home is experienced by the refugee Sri Lankan as the "desire for home", ${ }^{3}$ a yearning for the authentic home, while the depiction of the restless Australian heroine, who dispenses with relations of intimacy when they occur, points to the recognition of the "inauthenticity of the created aura of all homes" (George 1999, 175).

Throughout her work, De Kretser's politics of representation registers omissions and gaps in history and hegemonic narratives through the compensatory devices of invention and mimicry: hybridized ethnicity is seen as a construction, and identities of key characters are constituted by modes of creativity and performativity interwoven with rooted concepts of place and time. In The Lost Dog (2007) which explores masked racism and equates race with the hegemonic national culture Nellie Zhang, the hybridized girlfriend of the Anglo Indian protagonist, Tom, parodies ethnic difference by donning new disguises and attires and performing ethnic stereotyping. In Questions of Travel both white Australian and Asian protagonists move between free-floating, unformed notions of home, and essentialized notions of race and belonging. The archaic concepts of homeland that Mummery sees as one feature of diaspora communities appear in the novel's twin narratives, alongside the more ephemeral identity structures that come with mobility: travel, whether through political asylum or tourism, shows the potential for a renegotiated lifestyle and deterritorialized identity. 
By contrast to the decentring and destabilizing of white Anglo Celtic masculinity in Behind the Moon as represented by Bob Gibson when threatened by the Asian presence, and his son Gibbo, who willingly constructs an Asian affinity, Questions of Travel foregrounds the vulnerability of the white Australian woman, hinting at her traditional exclusion from the heterosexually-defined patriarchal core. The youthful heroine, Laura, who undertakes global travel, then works for a global travel agency (De Kretser herself once produced Lonely Planet guidebooks), is contrasted to a radically dispossessed Sri Lankan refugee, Ravi Mendes, who chooses to return to his war-torn homeland at the novel's end. Laura, who travels from Sydney to England on her aunt's inheritance, embodies the restlessness of early $20^{\text {th }}$ century white settlers who often returned to the metropolitan homeland. Living in England suits her complexion and appearance: she is "a large white girl, firm-fleshed, the flesh rose flushed, and fine grained. The bloom that would have begun to wilt, in Sydney was ancestrally suited to England's damp cold” (De Kretser 2012, 83). Despite this illusion of belonging, she remains a sojourner and onlooker: travel does not root her into the ethnic and cultural heritage of the ancestral homeland. By contrast, the well-educated Ravi, a Burgher Sinhalese from a comfortable, middleclass home in a town near Colombo leaves on a temporary visa for Australia out of fear for his own life after his wife and child are senselessly and brutally murdered.

De Kretser's narrative structure of intersecting chapters juxtaposes the origin, identities and life trajectories of her protagonists so that the first half of the novel concludes with Laura's return from her overseas sojourn, almost coinciding with Ravi's arrival in exile in Australia. She is the cosmopolitan, tourist-observer who roams the world as an always belated traveller, embodying ambivalence and uncertainty. Sri Lanka is one of her tourist destinations, and when Ravi finally meets 
her, his sudden perception of her implicit voyeurism when he discovers she is planning to visit his country, enrages him. By contrast, he is catapulted onto a path of diminished choices and undiminished longing for home; exile only distances him from his difficult circumstances without resolving his emotions, despite the gradual improvement of his circumstances while living in the country often known as "lucky".

At one level, De Kretser is testing out the emancipatory potential of multicultural discourse in her contrasting portraits of un/belonging. Questions of Travel shows little of the violent racial discrimination that appears in Teo's novel, where the protagonists are verbally attacked as "chinks" and "commie bastard boaties" by a drunk on the Glenelg tram (Teo 2005, 63-65). But there is some evidence of Ang's "inclusion by virtue of otherness" $(2001,146)$. Ravi is greeted with hospitality and acts of kindness upon his arrival on a tourist visa, followed by an application for asylum. But reaction to his hosts is mixed: "Ravi realised that she was kind, and that his need to get away from her was acute" (De Krester 2012, 248). He at first works at a menial job in a western suburbs nursing home, but later, through a network of influence, and appropriately for his education and vocational training, he is appointed an IT administrator for Ramsay, the global travel guide publishing company where Laura works. Despite the negativity of the official line on refugees in Australia in 2012 when the novel was published, and over 5000 Sri Lankan refugees who sought asylum in Australia were branded as illegal and taken to detention facilities like Christmas Island or returned (Juers 2013), he is surprisingly granted permanent residence, although the agonizingly protracted process means this possibly comes too late.

The intimacies and new ties which bind Teo's characters in the concluding multicultural scenario of Behind the Moon, and that suggest the greater possibilities 
available to second generation migrants whose "identities are constructed with far more agency" (Watkins 2016, PAGE, citing Julian 2015, 113 ), are seemingly unavailable to Ravi. After meeting some Ethiopian migrants and entertaining hopes of intimacy with the woman, Hana, he realises that such a relationship would have been a delusion and he turns increasingly to his family ties in Sri Lanka for anchorage. A sense of disempowerment creeps up on him, even when he develops a sense of fellow feeling -- "He couldn't shake off the feeling that things were slipping from his grasp" (De Kretser 2012, 23) -- experiencing the migrant's sense of inauthenticity and irrefutable alienation:

Ravi thought it likely that when Abebe, Hana and Tarik lived in a house, he would still be only a visitor, hovering. Look at Desmond Patternot [his Burgher relative in Sydney]; he had spent two thirds of his life and still lived in another country. Ravi could see himself ending up like that, his knowledge of Australia as formal as a string of recited [railway] stations. (436)

Yet the concern with racism and ethnic divisions at the national level is repositioned by the vibrant transnational cosmopolitanism evident in the novel's global orientation. Ravi's professional training in information technology in Sri Lanka enables him to construct a virtual homeland in Sri Lanka by developing a memorializing website in honour of his wife and child, and thus to mourn their deaths. These new modes of connectivity contrast to Bob Gibson's identification with "old Australia" in Behind the Moon, as opposed to the "new cosmopolitan culture" to which Tien Ho seems to belong but where Bob feels he is “just a gawky tourist” (Teo 2005, 283). De Kretser's novel shows a more achieved cosmopolitanism than Teo's and globalization's 
transformative impact appears in the "reflexive awareness of ambivalences in a milieu of blurring differentiations, and cultural contradictions" (Beck 2006, 3); yet the preoccupation with borders, sovereignty and exclusionary identities of nation states remains ideologically influential, as Ravi's decision to return to Sri Lanka implies, and this aligns Questions of Travel with Teo's concluding image of unity within the national space.

At another level, De Kretser returns to the "unsettled settler" myth of inauthentic belonging, which encourages reinventions of the meaning of home (Huggan 2007, xi), and exposes gaps and inconsistencies in the hegemonic white Anglo Celtic core. Laura's rootless travel in Asia and Europe constantly reminds her of being an Australian, but on return she discovers that she does not necessarily belong: seeing herself a stranger, she views Sydney as both an insider and foreigner. Ravi, by contrast, never comes to terms with the losses that drove him into exile, and despite signs that he could make a better life for himself in Australia, and driven by increasing homesickness and nostalgia, he decides to return to Sri Lanka regardless of the risk of being killed by his wife's nameless murderers or of finding himself a stranger there.

De Kretser's narrative shows that discrimination or various forms of “othering” occur to Ravi and other multicultural groups, but such ambivalent attitudes provoke little reaction from him (Lokugé 2016, PAGE). Instead his sojourn becomes increasingly intolerable because of his inability to break the psychological impasse of grief at the murder of his wife and child, to articulate his emotions. In Freudian terms, his incomplete mourning has led to a state of melancholia, a pathological form of unresolved grief for lost objects which are impossible to let go. The loss of his wife and son, and then the death of his mother while he is in exile, 
become conflated with the loss of his country. As Freud says, there is an unconscious dimension of loss in melancholia, for the subject "knows whom he has lost but not what it is he has lost in them" (Freud, 1917, 155; emphasis in original). In this emphasis De Kretser creates a different image of migrant unbelonging from that which appears in Hsu-Ming Teo's Behind the Moon and her earlier novel, Love and Vertigo (2000), or novels such as Arlene Chai's On the Goddess Rock (1989) and The Last Time I Saw Mother (1995) and Simone Lazaroo's The Australian Fiancé (2000), where alienation is attributable to racism, intolerance or mild discrimination ranging from non-acceptance to affectionate exoticization. These forms of alienation ultimately matter less to Ravi than his feelings of irrecoverable loss and fear of losing his originary identity. Although Mummery advocates the construction of hyphenated identities as a practice to be negotiated or a performance undertaken, therefore, it is clear that Ravi is unable to move beyond his historical circumstances to continue practising not-at-homeness; he returns to Sri Lanka driven by the wish to recapture an earlier version of home and belonging, entering into a totalizing horizon of identity, a form of revived ethnic essentialism, countering sensations of grief, absence, loss and distance with a belief in prior constructions of family and home.

Laura, by contrast, displays almost wilful alienation and rejection of originary belonging. Her career as a travel writer after she returns to Sydney, fostering a cosmopolitan lifestyle based on international travel and tourism, contrasts to the experience of the rooted, nationalist, Bob Gibson in Behind the Moon, whose inner turmoil over perceived Asian threats presence make him question his place "at home". Gibson's patriarchal heritage, informed by a militaristic, conformist ideology, is inadequate to deal with the demands of a multicultural society, as he realizes at the novel's end, yet his friendship with Justin's father -- "Everyone was surprised and 
appalled when Bob was converted to karaoke" (Teo 2005, 361) -- contributes to the reconciliatory multicultural ending. Lorna's vulnerability and tenuous hold on life is imaged in her lack of interest in putting down roots, her casual attitude to being at home, and the globalized culture and lifestyle which she has adopted. It is reflected in her friction with family members and hints of her potential victim status due to her gender and ethnicity: her twin brothers try to murder her when she is a baby; Ravi has murderous thoughts when he thinks of her as a tourist in Sri Lanka: "She loomed over him, sly and suggestive and -- I'd like to kill you he thought" (De Kretser 2012, 490). These premonitions are realized in the hand of God ending, where fate deals a final blow and she is swept away in the 2004 tsunami that hits Sri Lanka. Here, it seems, her unconscious acts of not-at-homeness contribute to her demise.

Questions of Travel, with its parallel narratives, invites a certain reading. In place of the socially divisive, conflictual discrimination and ugly racism that appears in other Asian Australian novels, Laura and her generation represent a greater tolerance for the Asian outsider as well as displaying more limited belonging within the nation space, as global positions, values and connections infiltrate and loosen national ties. Nor do the syncretic affiliations and potential solidarities that unite the characters in Behind the Moon work for Ravi in his encounter with other multicultural figures. His decision to turn his back on the hospitality and limited acceptance he has found and to return to Sri Lanka, portray an experience of loss, dislocation, and idealization of the homeland; this can be as attributed to the morbid state of melancholia, although elements of Ien Ang's “acceptance through difference” (2001, $139)$ and Deborah Madsen's “ambivalent hospitality” $(2006,120)$ can also be traced. Unlike Laura's mobility, which hints that the white Australian who takes national belonging for granted is in some way imperilled, Ravi's decision suggests a revaluing 
of diasporic deterritorialized notions of home and belonging, and a renewed appreciation of originary place, family and society.

In moving beyond the stark divisions of class, gender and ethnicity, also challenged in the conclusion of Behind the Moon, Questions of Travel suggests a shift in the national imaginary with greater sympathy demonstrated towards Asian migrants and asylum seekers, who in turn exercise a degree of choice over what home they want. It cannot be overlooked, however, that both authors may be writing ironically in response to critical debates as Ommundsen suggests $(2012,6)$. De Kretser's novel won the Miles Franklin Award in 2013, suggesting inter alia that its representation of plural social perspectives strikes a chord: white settler unbelonging is relativized alongside the experience of the alienated diasporic subject who, unusually, reverses the path of exile, yet takes something of Australia away with him: "Australia had entered Ravi. Now it would keep him company no matter where in the world he went" (De Kretser 2012, 264). Less marginal upon departure than on arrival, having acquired a degree of self-agency and ability to articulate his anger, the Asian figure contributes to the novel's rebranding of Australian identity as both global /transnational and national. De Kretser's narratives of the overlapping trajectories of a wandering white Australian protagonist and a dislocated Sri Lankan refugee who meet briefly in Sydney -- two images of estrangement and travel -- therefore moves the multicultural novel into a different national space from Teo's novel. Its very structure, in which equal narrative space is given to each of the two stories, hints at an attempt to symbolically realign the white Anglo presence with the multicultural marginal Asian one. In her devising "a more complex equation of difference" (Lee 2008, 214) between Australia and Asia in ways comparable to Teo, De Kretser nevertheless goes further in her strategic intervention into contemporary 
representational politics; her global novel implies that the white Australian

entitlement to belong often remains unconscious (Hage 1988, 19), and Laura's fate suggests that Australians who ignore such questions about belonging do so at their peril.

\section{Notes on contributor}

Janet Wilson is Professor of English and Postcolonial Studies at the University of Northampton, UK. She has published widely on the literature and cinema of the white settler societies of Australia and New Zealand, and recently "Discoursing on Slums: Representing the Cosmopolitan Subaltern" in Reworking Postcolonialism: Globalization, Labour and Rights, which she co-edited with Pavan Malreddy et al. (2015). She is Deputy Chair of the Katherine Mansfield Society, a member of the South Asian Diaspora International Research Network (SADIRN) at Monash University, where she also holds the position of Adjunct in the School of Languages, Literatures, Cultures and Linguistics, and co-editor of the Journal of Postcolonial Writing.

\section{Notes}

1 The Anglo Celts consist of the British, of pro-Monarchist and Protestant descent, and the Irish (sometimes Catholic) dissidents. On the homogeneous, monocultural "colour blind" concept of Anglo Celtic, see Huggan $(2007,76)$

${ }^{2}$ Dickens (2015) points out that theories of race, class and multiculturalism have not yet addressed these formations.

${ }^{3}$ The contrast between the two novels illustrates Avtar Brah's (1995) distinction between a "homing desire" and "the desire for a homeland" $(16,180)$.

\section{References}

Ang, Ien. 2001. On Not Speaking Chinese; Living between Asia and the West.

London and New York: Routledge.

Australian Human Rights Commission. 1997. "Bringing Them Home: Report of the National Enquiry into the Separation of Aboriginal and Torres Strait Islander Children from Their Families."

https://www.humanrights.gov.au/publications/bringing-them-home-report1997.

Beck, Ulrich, 2006. The Cosmopolitan Vision. Translated by Ciaran Cronin. Cambridge: Polity Press. 
Bhabha, Homi K. 2006. "Cultural Diversity and Cultural Differences.” In The Postcolonial Studies Reader, edited by Bill Ashcroft, Gareth Griffiths, and Helen Tiffin. 155-157. $2^{\text {nd }}$ ed. London: Routledge.

Bhabha, Homi K. (1994). The Location of Culture. London: Routledge.

Brah, Avtar. 1996. Cartographies of Diaspora. London and New York: Routledge.

Castro, Brian. [1983] 1989. Birds of Passage. North Ryde, NSW: Angus and Robertson.

Chai, Arlene. 1998. On the Goddess Rock. Sydney: Random House.

Chai, Arlene . 1996. The Last Time I Saw Mother. Sydney: Random House.

Chakrabarty, Dipesh. 2011. "Belatedness as Possibility: Subaltern Histories Once Again.” In The Indian Postcolonial: A Critical Reader, edited by Elleke Boehmer and Rosinka Chaudhuri, 163-176. London: Routledge.

De Kretser, Michelle. 2007. The Lost Dog. Sydney: Allen and Unwin.

De Kretser, Michelle. 2012. Questions of Travel. Sydney: Allen and Unwin.

Deleuze, Gilles, and Felix Guattari. 1988. A Thousand Plateaus: Capitalism and Schizophrenia. Translated by Brian Massumi. London: The Athlone Press.

Delrez, Marc. 2010. 'Fearful Symmetries: Trauma and 'Settler Envy' in Contemporary Australian Culture." Miscelánea: A Journal of English and American Studies 42: 51-65.

Dickens, Lyn. 2015. “The 'Shattered Racialised Person' and (Post)Multiculturalism in Australia." In Reworking Postcolonialism: Globalization, Labour and Rights, edited by Pavan Kumar Malreddy, Birte Heidemann, Ole Birk Laursen and Janet Wilson, 88-101. London: Palgrave Macmillan. 
Fortier, Anne-Marie. 2003. "Making Home: Queer Migrations and Notions of Attachment." In Uprootings/Regroundings: Questions of Home and Migration, edited by Sara Ahmed, 115-124. Oxford: Berg.

Freud, Sigmund. 1917 [1959]. "Mourning and Melancholia." In Sigmund Freud: Collected Papers, 5 vols. Translated by Joan Riviere, Vol. 4, 152-170. New York: Basic Books.

Freud, Sigmund. [1919] 1959. “The 'Uncanny'.” In Sigmund Freud: Collected Papers, 5 vols. Translated by Joan Riviere, Vol. 4, 368-407. New York: Basic Books.

George, Rosemary. 1996. The Politics of Home: Postcolonial Relations and Twentieth- Century Fiction. Cambridge: Cambridge University Press.

Gooneratne, Yasmine. 1991. A Change of Skies. Sydney: Picador Australia. Gunew, Sneja. 1990. "Denaturalizing Cultural Nationalisms: Multicultural Readings of Australia." In Nation and Narration, edited by Homi Bhabha, 99-120. London: Routledge.

Hage, Ghassan, White Nation: Fantasies of White Supremacy in a Multicultural Society. London: Pluto Press, 1988.

Hall, Stuart. 1990. “Cultural Identity and Diaspora.” In Identity: Community, Culture, Difference, edited by Jonathan Rutherford, 222-237. London: Lawrence and Wishart, 1990.

Huggan, Graham. 2007. Australian Literature: Postcolonialism, Racism, Transnationlism. Oxford: Oxford University Press.

Juers, Evelyn. 2013. “Tripped Up, Tripped Out: Review of Questions of Travel, by Michelle de Kretser.”Sydney Review of Books. January 29. $\underline{\text { http://sydneyreviewofbooks.com/tripped-up-tripped-out/ }}$ 
Julian, Roberta. 2015. "Ethnicity and Immigrations: Changing the National. Imaginary.” In Australian Sociology, edited by David Holmes, Kate Hughes, and Roberta Julian, 90-129. Melbourne: Pearson Australia.

Khoo, Tseen. 2008. "Introduction: Locating Asian Australian Cultures.” In Locating Asian Australian Cultures, edited by Tseen Khoo, 1-9. London: Routledge.

Khoo, Tseen, ed. 2008. Locating Asian Australian Cultures. London: Routledge.

Lai, Larissa. 2001. "Corrupted Lineage: Narrative in the Gaps of History.” Special Issue of West Coast Line 33-34 (3): 40-53.

Lazaroo, Simone. 2000. The Australian Fiancé . London: Picador.

Lee, Regina. 2008. “"Flexible Citizenship’: Strategic Chinese Identities in Asian Australian Literature.” In Locating Asian Australian Cultures, edited by Tseen Khoo, 213-227. London: Routledge.

Lo, Jacqueline. 2006. "Disciplining Asian Australian Studies: Projections and Introjections.” Journal of Intercultural Studies 27 (1-2): 11-27.

Lokugé, Chandani. 2016. "Mediating Literary Borders: Sri Lankan Writing in Australia.” Journal of Postcolonial Writing 52 (5).PAGES TO COME

Madsen, Deborah. 2006. "No Place Like Home': The Ambivalent Rhetoric of Hospitality in the Work of Simone Lazaroo, Arlene Chai and Hsu-Ming Teo." Journal of Intercultural Studies 27 (1-2): 117-132.

Mishra, Vijay. 2007. The Literature of the Indian Diaspora: Theorizing the Diasporic Imaginary. London: Routledge.

Morris, Robyn. 2008. “'Growing up an Australian': Renegotiating Mateship, Masculinity and 'Australianness' in Hsu-Ming Teo's Behind the Moon.” In Locating Asian Australian Cultures, edited by Tseen Khoo, 151-166. London: Routledge. 
Mummery, Ruth. 2006. "Being Not-At-Home: A Conceptual Discussion.” In Diaspora: The Australasian Experience, edited by Cynthia vanden Driessen and Ralph Crane, 27-44. New Delhi: Prestige Books.

Ommundsen, Wenche. 2012. "Transnational Imaginaries: Reading Asian Australian Writing." Journal of the Association for the Study of Australian Literature 12 (2): 1-8.

Perfect, Michael. 2014. Contemporary Fictions of Multiculturalism: Diversity and the Millennial London Novel. London: Palgrave Macmillan.

Tan, Carole. 2008. “The Tyranny of Appearance': Chinese Australian Identities and the Politics of Difference.” In Locating Asian Australian Cultures, edited by Tseen Khoo, 65-82. London: Routledge.

Teo, Hsu-Ming, 2005. Behind the Moon. Sydney: Allen and Unwin.

Watkins, Alexandra. 2016. "The diasporic slide: representations of second generation diasporas in Yasmine Gooneratne's A Change of Skies (1991) and in Chandani Lokugé's If The Moon Smiled (2000) and Softly As I Leave You (2011).” nal of Postcolonial Writing 52 (5): PAGES TO COME

Williams Mark. 1997. “Crippled by Geography: New Zealand Nationalisms.” In Not on Any Map: Essays on Postcoloniality and Cultural Nationalism, edited by Stuart Murray, 19-42. Exeter: Exeter University Press. 
